\title{
EFFECT OF AMMONIUM CHLORIDE ADMINISTRATION ON METABOLISM IN INFANTILE TETANY AND RICKETS \\ BY
}

\author{
NOAH MORRIS, M.D., \\ and \\ OLIVE MACRAE, M.D.
}

(From the Department of Pædiatrics, Glasgow University, and the Biochemical Laboratory, Royal Hospital for Sick Children, Glasgow.)

For many years various opinions have been expressed as to disturbances in acid-base equilibrium in rickets and infantile tetany. The view that rickets is essentially a condition of acid poisoning was promulgated many years ago and some workers ${ }^{1}$ still hold this view. Recently György ${ }^{2}$ has expressed the opinion that a state of acidosis, while not necessarily the fundamental feature, is certainly associated with rickets, and that calcification is prevented by the increased acidity of the bone-forming tissues. With reference to this latter statement, however, Bosanyi ${ }^{3}$ found that the pH of rachitic cartilage was more alkaline than the normal, being $7 \cdot 6$ in the former as compared with $7 \cdot 2$ in the latter. Most efforts to obtain direct proof of change in the acid-base equilibrium of the blood or tissues have met with equivocal results, and from the evidence indirectly obtained widely varying conclusions have been drawn. Schabad ${ }^{4}$ maintained that the very low urinary excretion of lime and phosphorus in the early stage of rickets was against the theory of increased acid production. Recent investigations in general support this conclusion. Zucker, Johnston and Barnett ${ }^{5}$ found that in rats a rachitic condition supervened much more quickly, and to a more marked degree, when the diet was less acid-forming in nature. Thus the substitution of calcium chloride for calcium lactate in a typical rachitic dietary led to the development of a milder type of rickets. Similarly, the addition of 2 per cent. ammonium chloride to the diet prevented rickets in rats, whereas the administration of 2 per cent. sodium bicarbonate even to a well-balanced diet led to marked rickets. Hess $^{6}$ found that when rickets was induced with a diet containing 11.5 times as much calcium as phosphorus, the administration of cod-liver oil or irradiated ergosterol, or exposure to ultra-violet light, only produced healing of the rachitic state when there was an excess of acid over basic elements in the diet, as occurred when calcium chloride was substituted for calcium carbonate in equi-molar amounts. On the other hand, Samuel and Kugelmass ${ }^{7}$ report experiments on rats in which rickets developed much more markedly on diets free of vitamin $\mathbf{D}$ when there was an excess of acid elements. 
The urinary excretion of acid and ammonia in rickets has been determined by several workers. Hodgson ${ }^{8}$ in 13 patients found an increase in the renal output of both acid and ammonia: Burgess and Osman ${ }^{9}$ also reported an increased excretion of ammonia. Freudenberg and György ${ }^{10}$, while confirming the increased output of ammonia, found that in some cases the urine was neutral or even alkaline.

Most workers are now agreed that the excessive loss of calcium and phosphorus in the fæces in rachitic conditions is the result, not of increased excretion through the gut-wall, but of defective absorption. The reaction of the alimentary tract has frequently been investigated during the past decade. McClendon ${ }^{11}$ and his co-workers in 1919 by direct electrometric investigation showed that normally the reaction of the whole of the small intestine in dogs and cats is on the acid side of neutrality. A year later they reported results indicating that in man the contents of the duodenum and jejunum have normally a $\mathrm{pH}$ below 7.0. In 1927 Lloyd Arnold $^{12}$ confirmed these findings in dogs. As far back as 1917 Schloss $^{13}$ pointed out that the reaction of the fæces was definitely alkaline in the active stage of rickets, and tended to become acid in the healing phase. Redman ${ }^{14}$ noted a certain correlation between the mineral content and $\mathrm{pH}$ of the fæces of rachitic children thus confirming the observations of Schloss. Experimentally it has been shown in rats that the active stage of rickets is accompanied by a definite alkaline reaction of the fæces, while during the process of healing induced by cod-liver oil or ultra-violet light there is a definite increase in acidity (Zucker and Matzer ${ }^{15}$, Jephcott and Bacharach ${ }^{16}$, etc.). Direct determinations of the $\mathrm{pH}$ of the contents of the small intestine in dogs show that on a rickets-producing dietary (Mellanby's) the reaction changed from acid to alkaline, while addition of cod-liver oil to the food or exposure to ultra-violet light produced a return to an acid reaction (Grayzell and Miller $\left.{ }^{17}\right)$. Similar findings are reported by Tisdall and Price ${ }^{18}$ in rats in which rickets had been produced. The consistency of these results provides almost conclusive proof that there is an actual change in the $\mathrm{pH}$ of the intestinal contents to the alkaline side in the active phase of rickets. While such a change in reaction would account for the defective absorption of calcium and phosphorus it is not sufficient to explain all the manifestations of the rachitic condition. Thus it has been shown experimentally that simple deprivation of lime, such as would occur if the sole abnormal factor were defective absorption, leads not to rickets but to osteo-porosis.

Present investigation.-The following investigation was undertaken to determine the effect of the administration of an acid-producing salt on the mineral metabolism in rickets and tetany. Ammonium chloride was the substance chosen to produce the acidosis, chiefly because in the gut it is neutral and therefore it was hoped that the influence of acidosis on the tissues could be studied without any direct action on the intestinal contents. It has already been shown by Gamble $^{19}$ and his co-workers and ourselves ${ }^{20}$ that 
calcium and phosphorus play an important part in dealing with a sudden excess of acid radicle in the tissues, at any rate until the ammonia formation has increased to such a pitch as to neutralize the extra acid. If the rachitic condition is accompanied by a state tending to acidosis it seems natural to expect that the organism will be less capable of dealing with the extra acid, especially when it is remembered that the bones are deficient in calcium and phosphorus.

The effect of ammonium-chloride administration on the calcium, phosphorus and chlorine metabolism was studied in four children who showed evidence of rickets. In three, in addition to a marked degree of active rickets shown by radiogram, there were present signs of tetany manifested by Chvostek's sign and in one laryngismus was also noted. In the fourth child the radiogram indicated that spontaneous healing was taking place during the period of the investigation. Two metabolic studies of seven days' duration were made in each patient. The diets were kept constant for three days prior to the commencement of the investigation and remained unchanged until the completion of the studies. In the second of the two ' metabolic' periods ammonium chloride was given in one gramme doses five times daily.

Clinical features.--No clinical signs of acidosis were manifest during the period of ammonium-chloride administration. In Case $1,5 \mathrm{grm}$. of ammonium chloride was given daily for 38 days without any obvious clinical indication of acidosis. In a previous investigation ${ }^{20}$ we noted that in the normal child a similar dosage of ammonium chloride was also without apparent clinical effect, and we attributed this result to the fact that the acid-producing salt when given in small amounts frequently, and not in one massive dose daily, allowed the metabolic processes to deal with the influx efficiently and thus prevent manifest disturbance. It is clear that in active rickets the power of the individual to deal with acid is at least as good as normal so far as the prevention of clinical manifestations of acidosis is concerned. During the administration of the ammonium chloride Chvostek's sign disappeared in all the cases. In Case 3, the laryngeal spasm also disappeared during the administration of ammonium chloride, but both it and Chvostek's sign returned on the day after the ammonium-chloride ingestion ceased, although in the other two patients there was no return of any sign of tetany.

Perhaps the most remarkable clinical feature noted was the appearance of healing in the radiogram of Case 1 after 38 days' administration of ammonium chloride although the environmental and dietetic conditions remained constant throughout this period. A series of weekly radiograms (Table 6, p. 57) indicate that the healing became apparent two weeks after the initiation of ammonium-chloride ingestion, and gradually increased until at the end of 38 days it was definite, although not nearly so marked as that which occurs with vitamin-D preparations or ultra-violet light. The fact 
that healing can take place during the administration of an acid-producing salt is in itself strong evidence against the view that there is in rickets a shift of acid-base equilibrium to the acid side. It may be urged that this patient was suffering from tetany. Nevertheless the occurrence of healing after the disappearance of Chvostek's sign indicates that in rickets the deposition of calcium can take place during the ingestion of a great excess of acid-producing substance.

Blood chemistry (Table 1).-The serum calcium which was abnormally low in all three patients (Cases 1, 2 and 3) with rickets and tetany showed a marked increase during ammonium chloride administration although the

TABLE 1.

Chavies in chenical composition of bloon.

\begin{tabular}{|c|c|c|c|c|c|}
\hline $\begin{array}{l}\text { Case } \\
\text { No. }\end{array}$ & Stage. & $\begin{array}{l}\text { Calcium } \\
\text { mgrm. \% }\end{array}$ & $\begin{array}{c}\text { Phosphorus } \\
\text { mgrm. } \%\end{array}$ & $\begin{array}{l}\mathrm{CO}_{2} \\
\text { vol. \% }\end{array}$ & $\begin{array}{l}\text { N.P.N. } \\
\text { mrgm. \% }\end{array}$ \\
\hline \multirow[t]{5}{*}{1} & Before $\mathrm{NH}_{4} \mathrm{Cl}$ administration & - & $3 \cdot 0$ & $50 \cdot 7$ & - \\
\hline & 3 weeks on $\mathrm{NH}_{4} \mathrm{Cl} \quad \ldots$ & $6 \cdot 1$ & $3 \cdot 4$ & $40 \cdot 3$ & $39 \cdot 5$ \\
\hline & $4 \quad$, & $6 \cdot 5$ & $4 \cdot 8$ & -- & - \\
\hline & $\pi \quad$, & $7 \cdot 4$ & $4 \cdot 2$ & $37 \cdot 8$ & $40 \cdot 9$ \\
\hline & 1 week after $\mathrm{NH}_{+} \mathrm{Cl}$ stopped & $6 \cdot 9$ & $2 \cdot 8$ & $59 \cdot 6$ & $31 \cdot 6$ \\
\hline \multirow[t]{2}{*}{2} & Before $\mathrm{NH}_{4} \mathrm{Cl}$ administration & $7 \cdot 6$ & $5 \cdot 6$ & $55 \cdot 6$ & $34 \cdot 8$ \\
\hline & 1 week on $\mathrm{NH}_{4} \mathrm{Cl} \quad \ldots \quad \ldots$ & $8 \cdot()$ & $3 \cdot 6$ & $44 \cdot 7$ & $44 \cdot 5$ \\
\hline \multirow[t]{2}{*}{3} & Before $\mathrm{NH}_{4} \mathrm{Cl}$ administration & $7 \cdot 6$ & $6 \cdot 2$ & $52 \cdot 5$ & $36 \cdot 3$ \\
\hline & 1 week on $\mathrm{NH}_{4} \mathrm{Cl}$ & $8 \cdot 9$ & $4 \cdot 6$ & $41 \cdot 4$ & $43 \cdot 1$ \\
\hline
\end{tabular}

normal level was not quite reached while the patients were under observation. The inorganic phosphorus content of the serum which was high in two patients (Cases 2 and 3 ) before the commencement of the ammonium chloride fell during that period, while in the third (Case 1), where it was initially low, an increase was noted for three weeks followed by a slow decline in its value. The total $\mathrm{CO}_{2}$ of the blood was lowered during the ammonium chloride administration while the chlorine tended to rise in value and the non-protein nitrogen showed no change. Generally it may be said that the changes in blood chemistry following the administration of ammonium chloride are the same in rachitic patients as they are in normal children. Further, it may be said that the results of blood analysis indicate the presence of what van Slyke has termed a compensated acidosis, just as occurs in healthy children under similar conditions, 


\section{Metabolism.}

It will be convenient first to summarize the metabolic results for each substance individually and thereafter to correlate the various findings.

Volume, titratable acidity and ammonia of urine (Table 2).-There was a slight increase in urinary volume in two of the cases during the ammoniumchloride period. In Case 3 the amount of urine was only half of that of the control period and in Case 4 (early healing) it was reduced by about one-tenth. The titratable acidity of the urine during the ammoniumchloride period was in none of the cases as greatly increased as it is in the

TABLE 2.

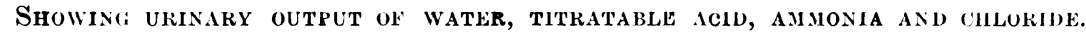

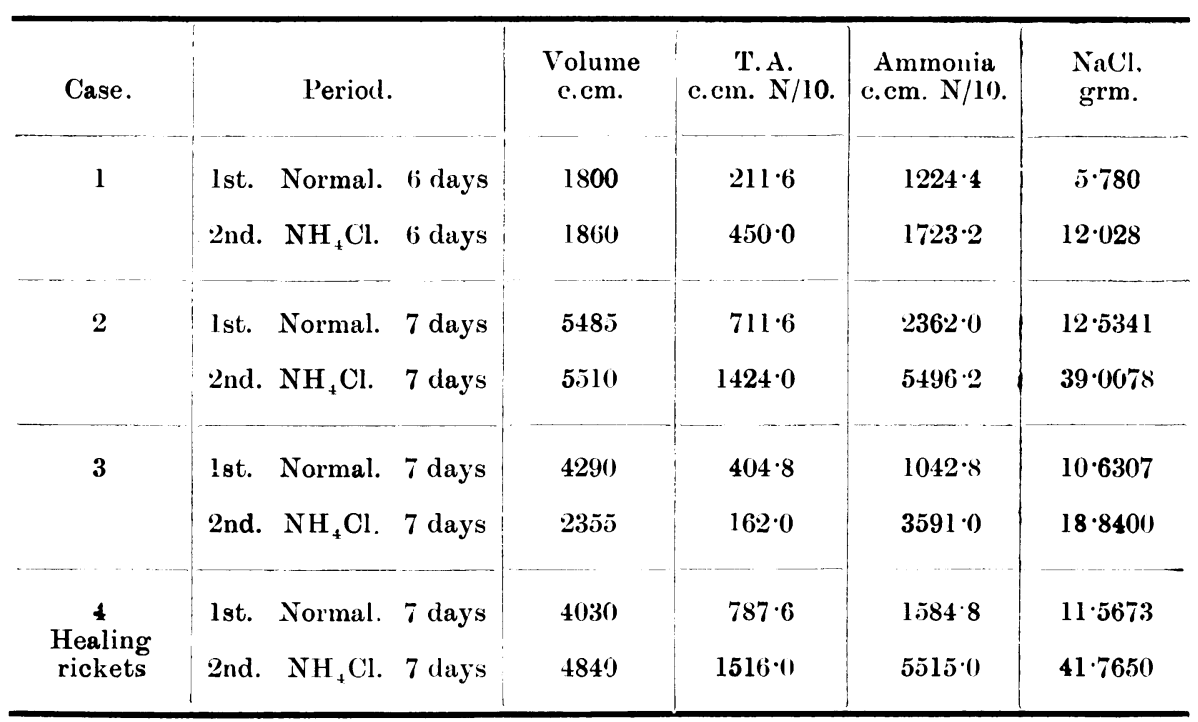

normal child: in Case 3 there was an actual decrease. There was a normal rise in the ammonia output in all except Case 1, where the increase was much less than normal.

Chlorine (Table 2). - The retention of chlorine in these four subjects shows a distinct variation from normal both in the control and ammoniumchloride periods. In normal children on an adequate milk diet the retention of chlorine varies from zero to about 12 per cent. of the intake. In all the four patients studied the chlorine retained amounted to over 12 per cent. of the intake. In Case 136.6 per cent. of the chlorine ingested over a six-day period was not excreted in the urine. Practically no chlorine was found in the fæces and as there was no noticeable perspiration, it is unlikely that the diminished urinary excretion was due to excess being passed out in the sweat. When the results of the ammonum-chloride periods are examined this tendency to retain chlorine becomes even more apparent. In normal 
children over 80 per cent. of the extra chlorine ingested is found in the urine. In the present series the percentage excreted fell far below that figure, except in Case 4 in which the rickets was healing and in whom the percentage excreted amounted to $\pi 8 \cdot 9$ per cent. of the extra intake.

Calcium and phosphorus (Tables 3 and 4).- In all instances administration of ammonium chloride led to an increased urinary output of lime and phosphorus. The increase was very marked in the case of healing rickets particularly in the output of calcium which was increased fourfold: in the others the increase was slight. The fæcal output of both lime and

TABLE 3.

SHOWIN: INTAKE, FACAT AND CRINARY OLTPUTS AND RETENTION OF CAICIUAI AND PHOSPHOKLS (IN GKAMMES). (7-DAY IERIODS).

\begin{tabular}{|c|c|c|c|c|c|c|c|c|c|c|c|}
\hline \multirow{3}{*}{ Case. } & \multirow{3}{*}{ Period. } & \multicolumn{2}{|c|}{ Intake. } & \multicolumn{4}{|c|}{ Output. } & \multicolumn{4}{|c|}{ Retention. } \\
\hline & & \multirow[t]{2}{*}{$\mathrm{CaO}$} & \multirow[t]{2}{*}{$\mathrm{P}_{20} \mathrm{O}_{\overline{5}}$} & \multicolumn{2}{|c|}{ Ficces. } & \multicolumn{2}{|c|}{ Urine. } & \multicolumn{2}{|c|}{ Total. } & \multicolumn{2}{|c|}{$\begin{array}{l}\text { Daily } \\
\text { per krrm. }\end{array}$} \\
\hline & & & & $\mathrm{CaO}$ & $\mathrm{P}_{2 .} \mathrm{O}_{3}$ & $\mathrm{CaO}$ & $\mathrm{P}_{22} \mathrm{O}_{5}$ & $\mathrm{CaO}$ & $\mathrm{P}_{2} \mathrm{O}_{5}$ & $\begin{array}{c}\text { Can } \\
\text { marrw. }\end{array}$ & $\underset{\text { mgrm. }}{\mathrm{P}_{2} \mathrm{O}_{5}}$ \\
\hline \multirow[t]{2}{*}{1} & 1. Normal & $s \cdot 208$ & $10 \cdot 80$ & 6.915 & $5 \cdot 3 ! 1$ & $\cdot 067$ & $3 \cdot 696$ & $1 \cdot 226$ & 1.803 & 30 & 44 \\
\hline & $2 . \mathrm{NH}_{4} \mathrm{Cl}$ & $s \cdot 208$ & $10 \cdot 80$ & $6 \cdot 293$ & $4 \cdot 644$ & $\cdot 084$ & $3 \cdot 740$ & $1 \cdot 831$ & $2 \cdot 416$ & 45 & 59 \\
\hline \multirow[t]{2}{*}{2} & 1 & $15 \cdot i 2$ & $21 \cdot 168$ & $13 \cdot 837$ & $11 \cdot 408$ & $\cdot 116$ & $7 \cdot 772$ & $1 \cdot 167$ & $2 \cdot 996$ & 12 & 21 \\
\hline & 2 & $15 \cdot 12$ & $21 \cdot 168$ & $9 \cdot 743$ & $8 \cdot 419$ & $\cdot 205$ & $8 \cdot 436$ & $5 \cdot 172$ & $5 \cdot 321$ & 57 & 47 \\
\hline \multirow[t]{2}{*}{3} & 1 & $12 \cdot 60$ & $17 \cdot 64$ & $9 \cdot 984$ & $12 \cdot 355$ & $\cdot 092$ & $2 \cdot 320$ & $2 \cdot 524$ & 3.805 & 37 & 44 \\
\hline & 2 & $12 \cdot 60$ & $17 \cdot 64$ & $9 \cdot 148$ & $11 \cdot 6 \mathrm{i} 6$ & $\cdot 146$ & $2 \cdot 754$ & $3 \cdot 306$ & $4 \cdot 110$ & 50) & 57 \\
\hline 4 & 1 & $12 \cdot 60$ & $16 \cdot 39$ & $7 \cdot 076$ & $4 \cdot 946$ & $\cdot 176$ & 6.512 & $5 \cdot 348$ & $3 \cdot 922$ & 75 & 55 \\
\hline $\begin{array}{l}\text { Heal- } \\
\text { ing }\end{array}$ & 2 & $13 \cdot 02$ & $16 \cdot 80$ & $9 \cdot 284$ & $7 \cdot 346$ & $\because 13$ & $7 \cdot 676$ & $3 \cdot 023$ & 1.778 & 41 & 17 \\
\hline
\end{tabular}

phosphorus was increased in Case 4 (healing), as a result of rise in fæcal weight and percentage of minerals in the fæces. In the patients with active rickets the output of lime and phosphorus in the fæces was greatly reduced; in Case 1 the reduction was due both to a fall in fæcal weight and in percentage content, while in Cases 2 and 3 the main factor was the reduction in the percentage content of lime and phosphorus of the fæces. It is of interest to note that in the patient (Case 3) who had the signs of tetany most marked, the phosphorus content of the fæces was very high and the combined fatty acids very low in both periods. The most striking difference between the behaviour of the patient with active rickets and that of the normal child or one with healing rickets is the increased retention of calcium and phosphorus in the former during ingestion of ammonium chloride and the decrease in the later. This is in accord with the radiographic evidence of definite healing in Case 1 already mentioned. 
TABLE 4 .

Showing ash, (alcivm, phosphorus and fat content of Faces (7-Day periods).

\begin{tabular}{|c|c|c|c|c|c|c|c|c|}
\hline \multirow[b]{2}{*}{ Case } & \multirow[b]{2}{*}{ Condition. } & & & & \multicolumn{2}{|c|}{ Period 1 (Normal). } & \multicolumn{2}{|c|}{ Period $2\left(\mathrm{NH}_{4} \mathrm{Cl}\right)$. } \\
\hline & & & & & $\begin{array}{c}\text { Total } \\
\text { quantity } \\
\text { in fæces } \\
\text { grm. }\end{array}$ & $\begin{array}{r}\% \text { in } \\
\text { faeces }\end{array}$ & $\begin{array}{c}\text { Total } \\
\text { quantity } \\
\text { in faces } \\
\text { grm. }\end{array}$ & $\begin{array}{l}\% \text { in } \\
\text { freces. }\end{array}$ \\
\hline \multirow[t]{8}{*}{1} & \multirow{8}{*}{$\begin{array}{l}\text { Active } \\
\text { rickets } \\
\text { and } \\
\text { tetany }\end{array}$} & Fæcal weigh & & $\ldots$ & $46 \cdot 1$ & - & $43 \cdot 40$ & - \\
\hline & & Ash $\quad \ldots$ & ... & & 一 & $31 \cdot 4$ & - & $29 \cdot 7$ \\
\hline & & $\mathrm{CaO} \quad \ldots$ & $\ldots$ & & 6.915 & 15 & $6 \cdot 293$ & $14 \cdot \overline{5}$ \\
\hline & & $\mathrm{P}_{2} \mathrm{O}_{5} \ldots$ & & & $5 \cdot 301$ & $11 \cdot 5$ & $4 \cdot 644$ & $10 \cdot 7$ \\
\hline & & Total fat & $\ldots$ & & $19 \cdot 929$ & $43 \cdot 23$ & $18 \cdot 857$ & $43 \cdot 45$ \\
\hline & & Combined fa & tty & ids & $15: 314$ & $33 \cdot 2 \cdot 2$ & $12 \cdot 551$ & $28 \cdot 92$ \\
\hline & & Eree fatty ac & cids & & $3 \approx 298$ & $7 \cdot 155$ & $5 \cdot 859$ & $13 \cdot 50$ \\
\hline & & Neutral fat & $\ldots$ & $\ldots$ & $1 \cdot 316$ & $2 \cdot 855$ & $0 \cdot 447$ & $1 \cdot 03$ \\
\hline \multirow{16}{*}{2} & \multirow{8}{*}{$\begin{array}{l}\text { Active } \\
\text { rickets } \\
\text { and } \\
\text { tetany }\end{array}$} & Fæcal weigh & & $\ldots$ & $73 \cdot 6$ & - & $52 \cdot 95$ & - \\
\hline & & Ash $\quad \ldots$ & $\ldots$ & & - & 40 & -- & 40 \\
\hline & & $\mathrm{CaO} \quad \ldots$ & $\cdots$ & & $13 \cdot 837$ & $18 \cdot 8$ & $9 \cdot 743$ & $18 \cdot 4$ \\
\hline & & $\mathrm{P}_{2} \mathrm{O}_{5} \quad \cdots$ & $\cdots$ & & $11 \cdot 408$ & $15 \cdot 5$ & $8 \cdot 419$ & $15 \cdot 9$ \\
\hline & & Total fat & $\cdots$ & & 20.939 & $28 \cdot 45$ & $17 \cdot 542$ & $33 \cdot 13$ \\
\hline & & Combined fa & tty & ids & $12 \cdot 622$ & $17 \cdot 15$ & $10 \cdot 521$ & $19 \cdot 87$ \\
\hline & & Free fatty ac & ids & & $5 \cdot 961$ & $8 \cdot 1$ & $5 \cdot 004$ & $9 \cdot 45$ \\
\hline & & Neutral fat & $\ldots$ & & $2 \cdot 355$ & $3 \cdot 2$ & $2 \cdot 017$ & $3 \cdot 81$ \\
\hline & \multirow{8}{*}{$\begin{array}{l}\text { Active } \\
\text { rickets } \\
\text { and } \\
\text { tetany }\end{array}$} & Fæcal weigh & & & $62 \cdot 4$ & - & $72 \cdot 6$ & - \\
\hline & & Ash $\ldots$ & $\ldots$ & & - & 45 & - & 45 \\
\hline & & $\mathrm{CaO} \quad \ldots$ & $\ldots$ & & $9 \cdot 984$ & $16 \cdot 0$ & $9 \cdot 148$ & $12 \cdot 6$ \\
\hline & & $\mathrm{P}_{2} \mathrm{O}_{5}$ & $\ldots$ & & $12 \cdot 355$ & $19 \cdot 8$ & $11 \cdot 6 \mathbf{i} 6$ & $16 \cdot 0$ \\
\hline & & Total fat & $\ldots$ & $\ldots$ & $17 \cdot 515$ & $28 \cdot 07$ & $18 \cdot 411$ & $25 \cdot 36$ \\
\hline & & Combined fa & tty & ids & $1 \cdot 622$ & $2 \cdot 60$ & $1 \cdot 365$ & 188 \\
\hline & & Free fatty a & ids & & $1 \cdot 2 \cdot 299$ & $19 \cdot 71$ & $10 \cdot 781$ & $14 \cdot 85$ \\
\hline & & Neutral fat & ... & $\ldots$ & $3 \cdot 594$ & $5 \cdot 76$ & $6 \cdot 265$ & $8 \cdot 63$ \\
\hline \multirow[t]{8}{*}{4} & \multirow{8}{*}{$\begin{array}{l}\text { Healing } \\
\text { rickets }\end{array}$} & Frecal weigh & & & $36 \cdot 1$ & - & $45 \cdot 07$ & 一 \\
\hline & & Ash $\quad \ldots$ & $\ldots$ & $\cdots$ & - & $38 \% 2$ & - & $42 \cdot 1$ \\
\hline & & $\mathrm{CaO} \quad \ldots$ & .. & $\ldots$ & $7 \cdot 076$ & $19 \cdot 6$ & $9 \cdot 284$ & $20 \cdot 6$ \\
\hline & & $\mathrm{P}_{2} \mathrm{O}_{;} \ldots$ & $\cdots$ & $\cdots$ & $4 \cdot 946$ & $13 \cdot 7$ & $7 \cdot 346$ & $16 \cdot 3$ \\
\hline & & Total fat & $\ldots$ & $\cdots$ & $6 \cdot 743$ & $18 \cdot 68$ & $7 \cdot 310$ & $16 \cdot 22$ \\
\hline & & Combined $f$ & ttty & ids & $4 \cdot 498$ & $12 \cdot 46$ & $4 \cdot 439$ & $9 \cdot 85$ \\
\hline & & Free fatty a & cids & & 0.975 & $2 \cdot 7$ & $1 \cdot 767$ & $3 \cdot 9: 2$ \\
\hline & & Neutral fat & $\ldots$ & $\ldots$ & $1 \cdot 270$ & $3 \cdot 52$ & $1 \cdot 104$ & $2 \cdot 45$ \\
\hline
\end{tabular}




\section{Discussion.}

The following differences are to be noted in the reaction of the rachitic patient to ammonium chloride from that of the normal child (Table 5).

1. There is an increase in the retention of lime and phosphorus in active rickets. When the rickets is healing ammonium chloride leads to a decrease in the retention of minerals as in health.

2 . A much smaller proportion of the extra chlorine ingested is excreted by the rachitic than by the normal individual.

3. The increase in the urinary excretion of titratable acid and ammonia is not so marked in active rickets as in health or healing rickets.

TABLE 5.

CoMParison OF THE METABOLIC REACTIONS OF NOKMAL AND TETANY-KICKETS GROUPS TO ACIDOSIS PRODUCRD BY AMMONIUM GHLORIDE.

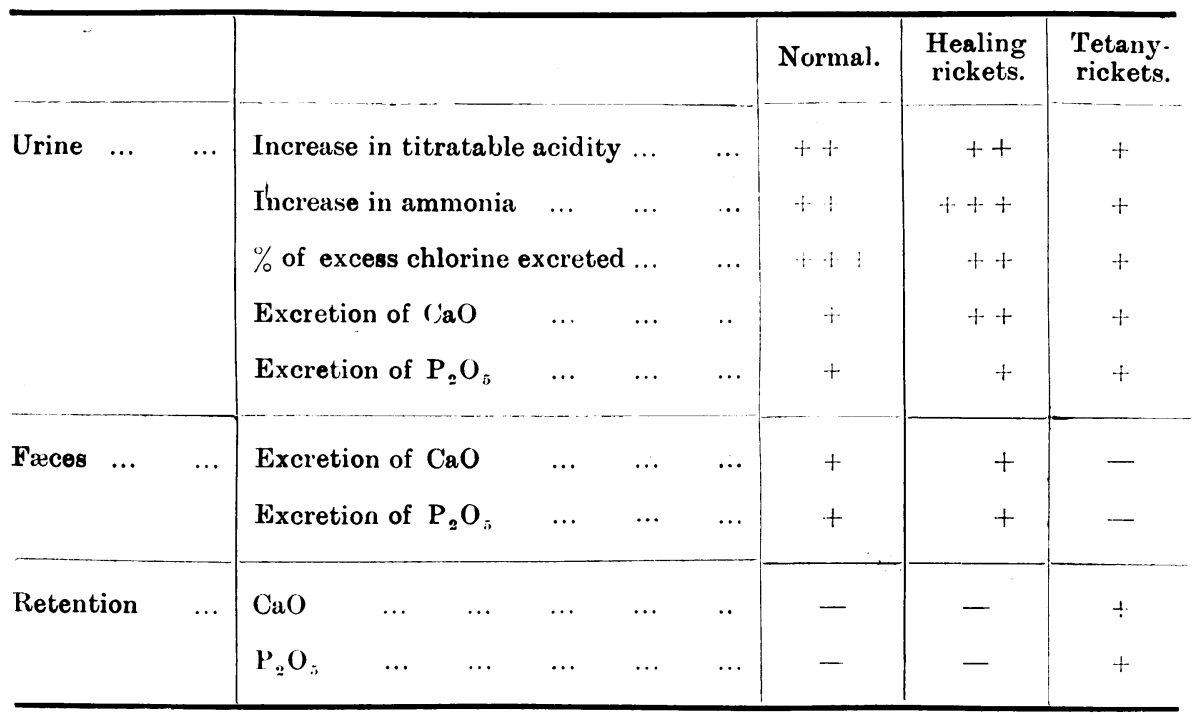

The increased retention of lime and phosphorus following ammonumchloride administration in active rickets is in marked contrast to what occurs in health and healing rickets. The use of acid-producing salts therapeutically as a softener of bones is well-known. Ammonium chloride was chosen in this study as an acid-producing substance because of its neutrality in the gut. Nevertheless the possibility must be conceded of its being able to decrease the $\mathrm{pH}$ in the intestine secondarily by its effect on the composition of the body fluids. In this way absorption of the mineral elements would be facilitated. It may further be urged that the increased retention resulting from ammonium-chloride administration is due to the fact that the mineralstarved bones utilize so much of the extra lime and phosphorus absorbed that the slight increase in the amount excreted is completely overshadowed. This contention cannot be upheld in view of the results recorded in the case of healing rickets. The mineral retention was here reduced during the 
ammonium-chloride period just as in the normal child in spite of the fact that, healing having just commenced, there was still osteo-porosis shown in the radiogram at the time of the study. To explain the effect of ammonium chloride in increasing the retention of lime and phosphorus in active rickets, it therefore seems necessary to assume that some change has been effected enabling the tissues of the patient with active rickets to fix calcium and phosphorus. If this assumption be granted the corollary must be drawn that in addition to a probable defect in the absorption of minerals from the intestine there also exists in or around the tissues a condition which prevents the fixation of lime and phosphorus. As soon as healing commences, although the bones are still very defective in mineral content, the state of the tissues is such that administration of ammonium chloride leads to increased mineral excretion just as occurs in the healthy child. The fact that an acid-producing salt like ammonium chloride can during the active stage of rickets lead to an increased fixation of lime and phosphorus makes it highly improbable that in active rickets acidosis is either a causal or an associated factor. In this connection two other findings in the present investigation are of importance.

1. Subnormal increase in urinary acidity. This might at first glance be attributed to the diminished output of urinary phosphorus providing a smaller amount of phosphate for conversion from the mono- to the di-hydrogen salt. This explanation, however, is not satisfactory since the increase in the renal excretion of phosphorus during ammonium chloride ingestion is high relative to the increase in titratable acid. It would appear, therefore, that in these cases the tendency is for acids to be retained.

2. Subnormal increase in the excretion of chlorine. Defective renal function might be suggested as the explanation of this finding. There was, however, in none of the cases any impairment of kidney function. It is true that the ammonium output did not rise to the extent found in healthy children after ammonium-chloride administration; but this is more readily explained on the assumption that acid being retained, there was obviously no need for as much extra alkali to be formed. Further, if in active rickets there is relative excess of fixed base that excess will be used in preference to ammonia for the transport of acid.

The fact that an acid radicle such as chlorine is retained to an extent far exceeding the normal is strong supporting evidence of the view that if there is any change in acid-base equilibrium in active rickets that change is towards the alkaline and not the acid side.

In connection with the retention of chlorine it is of interest to mention the findings of Morris, Watson and Morris ${ }^{21}$ in experimental tetany induced by thyro-parathyroidectomy or injection of guanidine. During both the latent and active periods of these types of tetany there occurred a very marked retention of chlorine. Analysis of the tissues showed that the tissue content of chlorine was markedly increased. Further, there was noted a 
relationship between the amount of chlorine retained, the quality and amount of protein breakdown, and the development of convulsions. When the protein katabolism was in great excess relative to the amount of available chlorine, active tetany ensued. This suggests an explanation of the effect of high-protein intake in the form of meat in the conversion of a latent to an active tetany. It will be seen, therefore, that our results in the three children with tetany and rickets corroborate these experimental findings.

The clinical findings show that ammonium chloride did not in any way aggravate the rachitic condition. As in normal individuals receiving similar dosage, there was no apparent symptom of acidosis. It is admitted that in three patients there was tetany, in which condition the beneficial action of acid-producing substances has long been known. Nevertheless, radiographic evidence of healing was marked in the one patient who was given ammonium chloride for a prolonged period. And in the other two subjects of tetany, although all signs disappeared within two days, continued administration of ammonium chloride did not lead to any untoward manifestation. If rickets were accompanied by an increased acid formation the accumulation of acid resulting from ammonium chloride should lead to an aggravation of the condition, or at least prevent healing. The clinical, radiographic and metabolic results all show exactly the opposite. It therefore seems justifiable to conclude that there is no tendency to acidosis in rickets.

Shohl ${ }^{22}$ and his colleagues have recently published results showing that in rats made rachitic on a high-calcium low-phosphorus diet (Steenbock 2965) serum analyses indicate a state of the acid-base equilibrium bordering on alkalosis. Thus, although there is no conclusive evidence in the work detailed in this paper that a condition of alkalosis exists, it is tempting to draw this conclusion.

\section{Summary.}

The administration of ammonium chloride to three patients with active rickets and latent tetany, and to one patient with early healing rickets produced no apparent signs of acidosis.

In the tetany-rickets group there was a definite increase in the retention of calcium and phosphorus, a subnormal increase in the output of titratable acid and a marked retention of the excess chlorine. In healing rickets there was a definite decrease in the retention of calcium and phosphorus, but a retention of the excess chlorine slightly above normal.

One patient who was given ammonium chloride over a period of five weeks showed radiographic and metabolic evidence of healing, although the dietetic and environmental conditions were kept unchanged.

The findings are discussed and it is concluded that there is no evidence of any tendency to acidosis in rickets. 
We desire to thank Dr. Leonard Findlay, at whose suggestion this research was undertaken, for his very helpful criticism during the course of the work. Thanks are also due to the Medical Research Council for defraying the expenses of the investigation and for a personal grant to one of us (N.M.).

\section{TABLE 6.}

Progress of healing in Case I as indicated by radograms.

$$
\text { (R.M., aet. } 2 \text { years, } 1 \text { month). }
$$

Date.

8.5.29 Admitted to hospital.

9.5.29 X-ray of wrist : active 1 ickets.

16.5.29 ,, ,. I.S.Q.

$23.5 .29 \quad$., $\quad$,. $\quad$ I.S.Q.

$\begin{array}{llll}1.6 .29 & . & \text {.. } & \text { I.S.Q. }\end{array}$

$6.6 .29 \quad$,. $\quad$, I.S.Q.

18.6.29 $\quad, \quad, \quad$ I.S.Q.

19.6.29 Commencement of administration of $\mathrm{NH}_{4} \mathrm{Cl} 1$ grm. 5 times daily.

29.6.29 X-ray of wrist: I.S.Q.

30.6.29 Administration of $\mathrm{NH}_{4} \mathrm{Cl}$ ceased.

10.7.29 X-ray of wrist : definite signs of early healing.

$24.7 .29 \quad, \quad,, \quad$ ? further advance in healing process.

31.7.29 Administration of $\mathrm{NH}_{4} \mathrm{Cl} 1 \mathrm{grm}$. five times daily again started.

12.8.29 X-ray of wrist : definite advance in healing process.

22.8.29 ., , further healing.

29.8.29 ,, , very slow healing progressing.

8.9.29 Administration of $\mathrm{NH}_{4} \mathrm{Cl}$ ceased.

9.9.29 X-ray of wrist: further healing.

\section{REFERENCES.}

1. Pritchard, E., Brit. Med. J., London, 1923, i, 887.

2. György, P., Érgebn. d. inn. Mediz. u. Kinderheilk., Berlin, 1929, XXXVI, 752.

3. Bosanyi, A., Jahrb. f. Kinderheilk., Berlin, 1927, CXVII, 240.

4. Schabad, Arch. f. Kinderheilk., Stuttgart, 1910, LIII, 380; 1910, LIV, 83.

5. Zucker, T. F., Johnson, W. C., \& Barnet, M., Proc. Soc. Exp. Biol. \& Med., N.Y., 1922, XX, 20.

6. Hess, A. F., Weinstock, M., Rivkin, H., \& Gross, J., Ibid., 1929, XXVII, 140.

7. Samuel, E. L., \& Kugelmass, I. N., Amer. J. Dis. Child., Chicago, 1930, XXXIX, 687.

8. Hodgson, A., Lancet, London, 1921, ii, 945.

9. Burgess, N., \& Osman, A. A., Ibid., 1924, i, 281.

10. Freudenberg, E., \& György, P., Münch. med. Wochen., München, 1922, XII, 42\%.

11. McClendon, J. F., Bessell, F. S., Lowe, E. R., \& Meyer, P. F., J. Amer. Med. Assoc., Chicago, 1920, LXXV, 1638.

12. Lloyd, A., Klin. Wochenschr., Berlin, 1927, i, 607.

13. Schloss, E., Ergeb. d. inn. Mediz. u. Kinderheilk., Berlin, 1917, XV, 55.

14. Redman, T., Biochem. J., Cambridge, 1929, XXIII, 256. 
15. Zucker, T. F., \& Matzner, M. J., Proc. Soc. Exp. Biol. \& Med., N.Y., 1923, XXI, 186.

16. Jephcott, H., \& Bacharach, A., Biochem. J., Cambridge, 1926, XX, 1350.

17. Grayzell, D. M., \& Miller, E. G., J. Biol. Chem., Baltimore, 1928, LXXVI, 423.

18. Tisdall, F., \& Price, H. W., Bull. Johns. Hopk. Hosp., Baltimore, 1927, XLI, 432.

19. Gamble, J. L., Ross, S. G., \& Tisdall, F., Amer. J. Dis. Child., Chicago, 1923, XXV, 455.

20. Morris, N., \& MacRae, O., Arch. Dis. Childh., London, 1930, V, 207.

21. Morris, S., Watson, A. M., \& Morris, N., Biochem. J., Cambridge, 1931, XXV, 786.

22. Shohl, A. T., Brown, H. B., Rose, C. S., Smith, D. N., \& Cozad, F., J. Biol. Chem. Baltimore, 1931, XCII, 711. 